\title{
PELATIHAN KOMPUTERISASI PENGELOLAAN DATA KEUANGAN PADA PKK RW 11 DESA ASRIKATON KECAMATAN PAKIS KABUPATEN MALANG
}

\author{
Heru Utomo ${ }^{1}$, Dwi Sudjanarti ${ }^{2}$ \\ 1,2 Jurusan Administrasi Niaga, Politeknik Negeri Malang \\ e-mail: ${ }^{1}$ heru.utomo@polinema.ac.id, ${ }^{2}$ dwi.sudjanarti@polinema.ac.id
}

\begin{abstract}
Abstrak
Pengelolaan keungan secara komputerisasi tidak diragukan lagi dapat mempermudah penggunanya dalam membuat dan mengelolah laporan keuangan. PKK RW 11 Desa Asrikaton Kecamatan Pakis Kabupaten Malang telah mempunyai koperasi yang diperuntukkan anggota. Koperasi ini bergerak di bidang simpan pinjam bagi anggotanya. Selain itu beberapa anggota koperasi juga mempunyai usaha mandiri di rumah maupun diluar rumah. Oleh karena itu kegiatan ini bertujuan untuk mewujudkan keterampilan pengurus maupun anggota koperasi dibidang komputerisasi laporan keuangan.

Kegiatan PKM ini dapat berjalan lancar, peserta pelatihan mendapatkan tambahan pengetahuan dan keterampilan untuk mengelolah data keuangan menggunakan komputer. Peningkatan kemampuan pengurus maupun anggata dalam mengelolah data keuangan koperasi maupun usaha mandiri dapat terus dikembangkan dari berbagai sumber.
\end{abstract}

Kata kunci-pengelolaan keungan, komputerisasi keuangan

\section{PENDAHULUAN}

\subsection{Analisis Situasi}

Pembangunan nasional adalah suatu bentuk upaya pemerintah dalam meningkatkan seluruh aspek kehidupan masyarakat, bangsa, dan negara. Salah satu arah pembangunan jangka panjang disebutkan dalam Garis-Garis Besar Haluan Negara (GBHN) adalah untuk meningkatkan kualitas manusia dalam masyarakat Indonesia. Pendidikan merupakan syarat mutlak untuk mewujudkan manusia Indonesia yang cerdas, unggul, dan memiliki semangat serta motivasi tinggi untuk berkontribusi demi kemajuan bangsa. Perguruan Tinggi sebagai salah satu lembaga pendidikan memiliki peran statregis mewujudkan amanat pembangunan nasional. Peran perguruan tinggi

tersebut tertuang dalam Tri Dharma Perguruan Tinggi.

Pengabdian kepada masyarakat adalah salah satu dharma dari Tri Dharma Perguruan Tinggi. Menurut Undang-Undang Republik Indonesia Nomor 12 Tahun 2012 Tentang
Perguruan Tinggi, pengabdian kepada masyarakat adalah kegiatan sivitas akademika yang memanfaatkan ilmu pengetahuan dan teknologi untuk memajukan kesejahteraan masyarakat dan mencerdaskan kehidupan bangsa. Berdasarkan pernyataan undangundang tersebut, pengabdian masyarakat merupakan salah satu tugas pokok perguruan tinggi yang melibatkan segenap sivitas akademika, termasuk di dalamnya adalah mahasiswa.

Seiring waktu era yang dinamis, perguruan tinggi tidak lagi semata pencetak sumber daya yang

memiliki titel untuk menjalani realitas di masyarakat, melainkan juga dipandang sebagai lembaga yang menciptakan sumber daya yang dapat menyelesaikan permasalahan di masyarakat. Pengembangan sumber daya pada masyarakat memiliki peranan strategis dalam perekonomian Indonesia, karena sebagian besar pelaku ekonomi berada pada sektor ini. Sehingga tolak ukur perekonomian di Indonesia sebenarnya tergantung dari seberapa besar kemajuan yang telah dicapai 
oleh masyarakat. Pada hakikatnya pemberdayaan masyarakat adalah upaya penguatan masyarakat untuk memperoleh informasi, pengetahuan, dan keterampilan yang harus dilakukan secara multi aspek, baik dari aspek masyarakatnya sendiri maupun aspek kebijakan lainnya (Harahap, 2012). Oleh karena itu kegiatan pengabdian kepada masyarakat ini bersifat memecahkan masalah, komprehensif, bermakna, dan tuntas.

Pengelolaan data keuangan merupakan hal penting bagi suatu usaha baik usaha besar maupun usaha yang masih relatif kecil. Data keuangan yang lengkap merupakan sumber data untuk membuat laporan keuangan yang baik. Menurut Hendriksen (2002), Penyusunan laporan keuangan ini bertujuan untuk mempertanggungjawabkan seluruh kegiatan yang telah direncanakan dalam pencapaian hasilnya. Pada dasarnya, suatu laporan keuangan merupakan hasil dari proses akuntansi sebagai alat komunikasi antara data keuangan atau kegiatan suatu perusahaan dengan data atau aktivitas tersebut.

Manfaat laporan keuangan adalah menyediakan informasi kondisi dan perkembangan keuangan yang berhubungan dengan perseorangan atau organisasi/perusahaan yang menjadi bahan pertimbangan untuk mengambil keputusan yang tepat dan akurat. memberikan informasi yang berguna bagi manajemen perusahaan. Adanya laporan keuangan yang baik tentunya akan membantu pemilik usaha untuk mengetahui perkembangan usahanya.

Peran wanita tidak saja berperan tunggal, tetapi juga dapat berperan ganda. Perkataan lain ibu rumah tangga tidak saja berperan dalam rumah tangga, tetapi juga berperan dilingkungannya atau peran sosial. Salah satu peran sosial adalah adanya kegiatan PKK. PKK RW 11 Desa Asrikaton Kecamatan Pakis Kabupaten Malang memiliki koperasi yang bergerak dalam bidang simpan pinjam untuk anggotanya, dan terdapat beberapa anggota yang juga memiliki usaha mandiri. Pengetahuan tentang pengelolaan data keuangan tentunya akan membantu pengurus PKK maupun anggota PKK yang memiliki usaha mandiri tersebut. Jika koperasi dan usaha mandiri tersebut dikelolah dengan manajemen yang baik dan secara professional, misalnya pencatatan pembukuan dilakukan secara baik serta dilakukan pemisahan kantara keuangan pribadi dengan keuangan usaha maka kinerja koperasi maupun usaha mandiri dapat diketahui.

Seiring dengan perkembangan teknologi informasi dan komunikasi saat ini, maka sudah selayaknya pengurus koperasi maupun anggotanya yang memiliki usaha mandiri untuk meningkatkan produktivitas dan efektivitas proses pengelolaan data keuangan. Hal ini untuk menunjang keberlangsungan hidup suatu organisasi terutama PKK RW 11 Desa Asrikaton Kecamatan Pakis Kabupaten Malang, dan anggota PKK tersebut yang memiliki usaha mandiri.

\subsection{Rumusan Masalah}

Laporan keuangan yang baik memang tidak diragukan lagi berperan penting dalam mengelolah keuangan organisasi maupun usaha mandiri. Dengan adanya laporan keuangan yang baik tentunya akan dapat diketahui perkembangan usaha dari organisasi tersebut. Seiring kemajuan Teknologi Informasi dan Komunikasi (TIK) saat ini, maka komputer dapat dimanfaatkan untuk membuat laporan keuangan dengan lebih mudah dan lebih efisien. Mengacu kepada butir Analisis Situasi, maka rumusan masalah yaitu:

a. Bagaimana Pencatatan keuangan baik keuangan kas PKK maupun koperasi PKK RW 11 Desa Asrikaton Kecamatan Pakis Kabupaten Malang?

b. Apakah anggota PKK RW 11 Desa Asrikaton Kecamatan Pakis Kabupaten Malang yang mempunyai usaha mandiri melakukan pemisahan keuangan untuk usahan dan pribadi?

c. Apakah anggota PKK RW 11 Desa Asrikaton Kecamatan Pakis Kabupaten Malang yang mempunyai usaha mandiri telah melakukan pencatatan keuangan terhadap kegiatan usahanya?

Bagaimana pengetahuan pengurus dan anggota PKK RW 11 Desa Asrikaton Kecamatan Pakis Kabupaten Malang tentang microsoft excel untuk pengeloalaan data keuangan?

\subsection{Tujuan dan Manfaat Kegiatan PKM}

Tujuan dari kegiatan pengabdian pada masyarakat ini adalah: 
1. Memberikan pelatihan dalam bidang iptek, khususnya aplikasi software Microsoft Excel yang dapat digunakan untuk mengelolah data keuangan kepada PKK RW 11 Desa Asrikaton Kecamatan Pakis Kabupaten Malang.

2. Membekali pengurus PKK RW 11 Desa Asrikaton Kecamatan Pakis Kabupaten Malang keterampilan mengelolah data keuangan dengan aplikasi software Microsoft Excel.

3. Mengoptimalkan kesadaran anggota PKK RW 11 Desa Asrikaton Kecamatan Pakis Kabupaten Malang yang memiliki usaha mandiri untuk melakukan pemisahan keuangan usaha dengan keuangan pribadi, serta keterampilan mengelolah data keuangan dengan aplikasi software Microsoft Excel.

4. Menjalin hubungan yang lebih erat antara Politeknik Negeri Malang dengan masyarakat, khususnya pihak pengurus dan anggota PKK RW 11 Desa Asrikaton Kecamatan Pakis Kabupaten Malang.

Manfaat yang diharapkan dari kegiatan pengabdian pada masyarakat ini adalah:

1. Bagi pelaksana kegiatan PKM, dengan melaksanakan kegiatan pelatihan mengenai "Pelatihan Komputerisasi Pengelolaan Data Keuangan Pada PKK RW 11 Desa Asrikaton Kecamatan Pakis Kabupaten Malang" sebagai implementasi dari keilmuan yang telah dipelajari dan dikembangkan dalam kegiatan tri dharma perguruan tinggi.

2. Bagi lembaga, terjalinnya kerja sama dengan fihak luar dan sebagai bentuk kepedulian Politeknik Negeri Malang pada program Kementerian Pendidikan dan Kebudayaan dalam upaya potensi dan kreativitas Sumber Daya Manusia (SDM) di masyarakat, khususnya di pengurus dan anggota PKK RW 11 Desa Asrikaton Kecamatan Pakis Kabupaten Malang.

3. Bagi pengurus dan anggota PKK RW 11 Desa Asrikaton Kecamatan Pakis Kabupaten Malang, mendapatkan

$\begin{array}{lcr}\text { pengetahuan } & \text { dan } & \text { keterampilan } \\ \text { mengelolah } & \text { data } & \text { keuangan } \\ \text { menggunakan } & \text { software } & \text { Microsoft } \\ \text { Excel. } & & \end{array}$

\section{TINJAUAN PUSTAKA}

\subsection{Pengertian Laporan Keuangan}

Pada setiap akhir usaha, setiap perusahaan atau lembaga usaha menyusun laporan keuangan yang selanjutnya dilaporkan kepada pihak-pihak yang berkepentingan. Laporan Keuangan merupakan alat yang sangat penting untuk mendapatkan informasi sehubung dengan posisi keuangan dan hasilhasil yang dicapai oleh perusahaan. Kasmir (2014:7) menyatakan bahwa laporan keuangan adalah laporan yang menunjukkan kondisi keuangan perusahaan pada saat ini atau dalam suatu periode tertentu. Menurut Munawir (2007:56), laporan keuangan merupakan alat yang sangat penting untuk memperoleh informasi sehubungan dengan posisi keuangan dan hasil-hasil operasi yang telah dicapai oleh perusahaan yang bersangkutan.

Laporan Finansiil (Financial Statement), memberikan ikhtisar mengenai keadaan finansiil suatu perusahaan, dimana Neraca (Balance Sheets) mencerminkan nilai aktiva, utang dan modal sendiri pada suatu saat tertentu, dan laporan Rugi dan Laba (Income Statement) mencerminkan hasil-hasil yang dicapai selama periode tertentu, biasanya meliputi periode satu tahun (Riyanto, 2012:327).

Berdasarkan definisi-definisi di atas dapat disimpulkan bahwa laporan keuangan merupakan hasil akhir atau produk dari proses akuntansi yang terdiri dari proses pencatatan, pengelompokan, pelaporan, dan penginterpretasian yang isinya merupakan data historis dan masa kini dari perusahaan dalam satuan uang, ditujukan kepada kalangan internal dan eksternal perusahaan dalam pengambilan keputusan.

\subsection{Tujuan Laporan Keuangan}

Dibuatnya laporan keuangan oleh suatu perusahaan tentunya memiliki tujuan dan manfaat. Menurut Fahmi (2012:5), tujuan laporan keuangan adalah untuk memberikan informasi kepada pihak yang membutuhkan 
tentang kondisi suatu perusahaan dari sudut angka dalam satuan moneter.

Secara lebih rinci, Kasmir (2014:10), mengungkapkan bahwa laporan keuangan bertujuan untuk :

1. Memberikan informasi tentang jenis dan jumlah aktiva (harta) yang dimiliki perusahaan pada saat ini.

2. Memberikan informasi tentang jenis dan jumlah kewajiban dan modal yang dimiliki perusahaan pada saat ini.

3. Memberikan informasi tentang jenis dan jumlah pendapatan yang diperoleh pada suatu periode tertentu.

4. Memberikan informasi tentang jumlah biaya dan jenis biaya yang dikeluarkan perusahaan dalam suatu periode tertentu.

5. Memberikan informasi tentang perubahan- perubahan yang terjadi terhadap aktiva, pasiva, dan modal perusahaan.

6. Memberikan informasi tentang kinerja manajemen perusahaan dalam suatu perode.

7. Memberikan informasi tentang catatancatatan atas laporan keuangan.

Dari beberapa pendapat para ahli tersebut dapat dipahami bahwa tujuan laporan keuangan adalah untuk memberikan gambaran dan informasi yang jelas bagi para pengguna laporan keuangan terutama bagi manajemen suatu perusahaan.

\subsection{Komponen Laporan Keuangan}

Penyajian laporan keuangan yang lengkap terdiri dari lima komponen, berikut: (IAI, 2014:1.3)

1. Neraca merupakan laporan yang menggambarkan posisi keuangan perusahaan pada suatu tanggal tertentu.

2. Laporan Laba-Rugi menggambarkan jumlah hasil biaya dan laba-rugi perusahaan.

3. Laporan Perubahan Ekuitas adalah laporan yang menunjukkan rekonsiliasi saldo awal ekuitas hingga menunjukkan saldo akhir ekuitas. Rekonsiliasi tersebut berasal dari tambahan investasi, laba rugi usaha, dan pendistribusian hasil untuk pemilik (dividend atau drawing).

4. Laporan Arus Kas merupakan laporan yang menyajikan arus kas perusahaan selama periode tertentu dan diklasifikasikan menurut aktivitas operasi, investasi, dan pendanaan.

Catatan Atas Laporan Keuangan (CALK) merupakan penjelasan-penjelasan mengenai nilai, angka, maupun unsur-unsur lain yang terdapat dalam laporan keuangan, termasuk kebijakan dan metode akuntansi yang digunakan.

\section{SOLUSI DAN LUARAN}

\subsection{Solusi}

Berdasarkan informasi yang diperoleh terkait permasalahan mitra seperti yang diuraikan sebelumnya, tim pengabdian ingin membantu memberikan solusi terhadap permasalahan yang dihadapi mitra. Permasalahan yang dihadapi adalah kurangnya pemahaman atau kesadaran pengurus PKK dan anggota PKK yang memiliki usaha mandiri dalam proses pengolahan data keuangan yang benar dan mudah. Solusi yang ditawarkan adalah subagai berikut:

a. Masalah Pencatatan Keuangan

Solusi dari masalah pencatatan keuangan adalah dilakukan penyuluhan dan pendampingan dalam melakukan pencatatan keuangan. Pada tahap awal-awal sesuai dengan masalah yang dihadapi mengenai kontrol keuangannya terutama mengenai arus kas yang terjadi di dalam usaha, maka disarankan agar pemilik usaha menggunakan sistem nota untuk mencatat pengeluaran dan pemasukan. Dalam hal pengeluaran misal untuk belanja bahan baku selalu minta nota dari pembeli, jika tidak ada maka catatlah dengan menggunakan nota kosong. Begitu pula dengan jika ada penjualan, maka transaksi yang terjadi catatlah menggunakan nota. Setelah itu disarankan menyimpan nota tersebut, dan dilakukan kontrol sebulan sekali untuk memonitor keadaan uang masuk dan keluar. Untuk masalah penggunaan uangnya terutama untuk kebutuhan pribadi, akhirnya disarankan untuk menyisihkan sebagian laba yang diperoleh setiap transaksi. Pemisahan ini dilakukan agar pemilik usaha tidak mengambil uang usaha untuk keperluan pribadinya. Selain itu, hal ini berguna agar kebutuhan modal kerjanya juga tetap terjaga, terutama untuk pembelian bahan baku. 
b. Masalah Pengelolaan Data Keuangan

Solusi dari masalah pengelolaan data keuangan adalah pengelolaan data keuangan yang mudah dengan bantuan pelatihan pengelolaan data keuangan menggunakan software aplikasi microsoft excell.

Solusi yang ditawarkan di atas adalah untuk peningkatan kemampuan dan keterampilan pengurus dan anggota PKK RW 11 Desa Asrikaton Kecamatan Pakis Kabupaten Malang, agar proses pengelolaan data keuangan dapat dilakukan secara benar dan mudah dengan penggunaan software aplikasi microsoft excell.

\subsection{Target}

Target dari pelatihan komputer ini adalah memberikan pemahaman dan keterampilan penggunaan aplikasi komputer yaitu microsoft excel yang dapat dimanfaatkan dalam mengelolah data keuangan dengan benar dan mudah. Dengan materi yang diberikan diharapkan dapat meningkatkan pemahaman dan keterampilan pengurus dan anggota PKK RW 11 Desa Asrikaton Kecamatan Pakis Kabupaten Malang

\subsection{Luaran}

Luaran kegiatan pengabdian kepada masyarakat ini adalah:

a. Peserta memahami kosep pengelolaan data keuangan dan pentingnya melakukan pencatatan keuangan baik keuangan organisasi maupun keuangan untuk kegiatan usaha yan dilakukan oleh peserta. Peserta diberikan materi terkait pengelolaan data keuangan untuk memahami maksud dan konsep pengelolaan data keuangan. Masingmasing unsur dalam membuat laporan keuangan dijelaskan dan dikenalkan kepada peserta. Tolak ukur pemahaman peserta dilihat pada proses evaluasi terkait materi.

b. Kemampuan peserta dalam menggunakan aplikasi microsoft excell untuk pengolahaan data keuangan. Pada kegiatan ini diberikan materi terkait microsoft excell sebelum menggunakan aplikasi tersebut. Aplikasi microsoft excell dijabarkan dan didemonstrasikan, agar peserta mengetahui manfaat microsoft excell untuk pengolahan data keuangan. Selain itu dilakukan pendampingan kepada peserta agar peserta mampu mengoperasikan aplikasi microsoft excell. Tolak ukur pemahaman peserta dilihat pada proses evaluasi terkait materi.

Laporan dari pelaksanaan kegiatan pengabdian pada masyarakat yang dibuat oleh tim PKM berdasarkan format yang telah ditentukan.

\section{METODE}

Metode pelaksanaan pada kegiatan pengabdian kepada masyarakat ini dilaksanakan dengan tiga tahap, yaitu:

1. Persiapan

Sebagai langkah awal dalam pelaksanaan program PKM akan dilakukan survey pendahuluan ke daerah mitra. Survey dilakukan untuk mengetahui permasalahan mitra dan mencari solusi bersama ketua PKK. Menentukan calon peserta pelatihan yang akan dan bersedia mengikuti pelatihan.

\section{Pelaksanaan}

Setelah didapatkan peserta pelatihans sebanyak 15 orang yang terdiri dari pengurus dan anggota PKK yang memiliki usaha mandiri, maka dilaksanakan program pelatihan komputerisasi pengolalaan data keuangan. Pada tahap ini dilakukan dengan metode berikut:

a. Ceramah berfungsi untuk proses alih pengetahuan tentang materi bagaimana mengelolah data keuangan, meliputi serangkaian topik tentang apa yang dimaksud laporan keuangan dan bagaimana membuat serta mengelolanya secara komputerisasi menggunakan aplikasi microsoft excel. Sehingga laporan keuangan tersebut mampu membatu peserta mengelolah laporan keuangan koperasi maupun usaha mandiri yang dimilikinya .

b. Praktek

Kegiatan pratek dilaksanakan agar peserta pelatihan dapat mempraktekkan aplikasi teori/materi yang telah disampaikan. Pada kegiatan ini dilakukan pendampingan kepada peserta pelatihan oleh tim kegiatan pengabdian kepada masyarakat.

c. Diskusi 
Diskusi dan tanya jawab dilaksanakan untuk memberikan ruang kepada khalayak sasaran dalam memahami lebih lanjut tentang materi yang disampaikan serta membantu membangun hubungan yang lebih erat antara pelaksana kegiatan Pengabdian Kepada Masyarakat (PKM) dengan khalayak sasaran. Tanya jawab juga dilakukan pada saat praktek untuk memastikan bahwa semua peserta pelatihan atau perserta PKM telah memahami instruksi yang diberikan.

d. Pembahasan Masalah

Pada kegiatan ini peserta pelatihan akan diberikan sejumlah latihan yang sesuai dengan materi yang telah diberikan. Hal ini dilakukan untuk mempersiapkan peserta pelatihan terhadap bermacammacam variasi masalah dalam mengelolah data-data keuangan dengan Microsoft Excell.

3. Evaluasi

Tahap ini dilakukan untuk mengetahui mengenai tingkat ketercapaian tujuan pelatihan meliputi hal-hal sebagai berikut:

a. Evaluasi terhadap penyerapan materi Microsoft Excell yang telah diberikan melalui serangkain latihan soal yang sesuai dengan materi.

b. Evaluasi terhadap penyerapan materi Microsoft Excell yang telah diberikan melalui serangkain soal yang sesuai dengan permasalahan yang terjadi atau dihadapi oleh pesera pelatihan.

\section{HASIL DAN PEMBAHASAN}

\subsection{Hasil}

Tim pengabdian kepada masyarakat memulai kegiatan dengan menghubungi Ketua PKK RW 11 Desa Asrikaton Kecamatan Pakis Kabupaten Malang untuk menjelaskan maksud dan tujuan kegiatan pengabdian kepada masyarakat. Ketua PKK kemudian menyambut kegiatan ini dengan baik dan menyatakan bahwa ibu-ibu anggota PKK akan dengan senang hati ikut terlibat di kegiatan ini. PKK RW 11 Desa Asrikaton Kecamatan Pakis Kabupaten Malang memiliki koperasi simpan pinjam bagi anggotanya walaupun masih relatif kecil, dan beberapa anggota PKK ada yang mempunyai usaha mandiri. Pada pertemuan ini ketua PKK dan tim pengabdian kepada masyarakat sepakat bahwa peserta pelatihan ini

sebanyak 15 orang, yaitu pengurus PKK dan anggota yang memliki usaha mandiri.

Kegiatan Pengabdian Kepada Masyarakat (PKM) yang berupa pelatihan komputerisasi pengelolaan data keuangan pada PKK RW 11 Desa Asrikaton Kecamatan Pakis Kabupaten Malang telah dilaksanakan di laboratorium komputer Jurusan Administrasi Niaga Politeknik Negeri Malang yang beralamatkan di Jalan Soekarno Hatta 9 Malang. Pelatihan komputerisasi untuk pengolahan data keuangan ini dilaksanakan sebanyak 2 kali hari sabtu 26 September 2020 dan 27 September 2020. Pelatihan dimulai dari pukul 9.00 sampai dengan 15.00. Peserta yang hadir sebanyak 15 orang, yaitu pengurus PKK dan anggota yang memliki usaha mandiri.

\subsection{Pembahasan}

Fakta dilapangan pada saat sebelum pelaksanaan praktek kegiatan pengabdian kepada masyarakat ditemukan bahwa peserta merasa bahwa untuk mengelolah data-data keuangan menggunakan komputer atau menggunakan software microsoft excel membutuhkan kemampuan/keahlian tingkat tinggi atau dengan kata lain menggunakan komputer itu sangat sulit dan merepotkan. Belum tumbuhnya kreativitas dan kurangnya pengetahuan tentang adanya software aplikasi yan dapat mengelolah data keuangan dengan mudah menyebabkan peserta dalam mengelolah data keuangan PKK, koperasi PKK dan usaha mandiri bagi yang memilikinya hanya pencatatan sekedarnya. Pencatatan yang sekedarnya tersebut menyebabkan kesulitan untuk mengetahui data-data keuangan jika diperlukan. Setelah dilakukan penyampaian materi pada pertemuan pertama peserta mulai mengetahui tentang pentingnya mengelolah atau melakukan pencatat keuangan yang baik dan mulai memiliki minat yang tinggi melakukan pencatatan keuangan yang baik dan benar. PKK RW

Respon para peserta pelatihan (ibu-ibu

11 Desa Asrikaton Kecamatan Pakis Kabupaten Malang) yang sangat luar biasa merupakan modal bagi keberhasilan tujuan dari kegiatan pengabdian kepada masyarakat 
ini. Hasil pelatihan ini dapat diterapkan dan dimanfaatkan oleh pengurus PKK dan anggota PKK RW 11 Desa Asrikaton Kecamatan Pakis Kabupaten Malang yang memiliki usaha mandiri, serta dapat ditularkan kepada anggota PKK yang tidak dapat mengikuti kegiatan ini.

Evaluasi kegiatan pengabdian kepada masyarakat ini dilakukan untuk mengetahui tingkat penyerapan peserta terhadap materi yang telah diberikan. Evaluasi kegiatan dilakukan denga 2 cara sebagai berikut:

1. Memberi pertanyaan berkaitan dengan materi laporan keuangan, pengelolaan data-data keuangan, dan pemisahan keuangan usaha dengan keuangan pribadi. Berdasarkan pernyataan-pernyataan atau jawaban-jawaban peserta pelatihan menunjukkan bahwa peserta pelatihan memiliki kemauan untuk melakukan pengelolaan data keuangan baik keuangan PKK, koperasi PKK maupun keuangan usaha bagi anggota PKK yang memiliki usaha mandiri.

2. Evaluasi juga dilakukan secara langsung pada aplikasi microsoft excel dengan melihat penggunaan fitur-fitur yang tersedia dan yang diajarkan selama kegiatan. Evaluasi dilakukan dengan melihat di aplikasi microsoft excel apakah peserta sudah dapat menggunakan fitur dan mengerjakan latihan dan tugas yang diberikan. Sebagian besar peserta dapat langsung mencoba, menggunakan, dan mengerjakan latihan dan tugas yang telah diberikan

\section{SIMPULAN DAN SARAN}

\subsection{Simpulan}

Kegiatan Pengabdian Kepada Masyarakat (PKM) dalam bentuk pelatihan komputerisasi pengelolaan data keuangan pada PKK RW 11 Desa Asrikaton Kecamatan Pakis Kabupaten Malang telah dapat dilaksanakan dengan lancar di laboratorium komputer Jurusan Adminstrasi Niaga Politeknik Negeri Malang. Kegiatan ini melibatkan tim pengabdian kepada masyarakat yaitu dosen Jurusan Adminstrasi Niaga Politeknik Negeri Malang yang ahli dibidang komputer, manajemen pemasaran, dan bahasa jepang. Pelatihan dilakukan dalam 2 kali pertemuan dalam bentuk ceramah/presentasi, pendampingan praktek, diskusi dan tanya jawab.

Respon peserta pengabdian yaitu ibuibu PKK RW 11 Desa Asrikaton Kecamatan Pakis Kabupaten Malang sangat baik. Peserta mempunyai semangat yang tinggi setelah mengetahui manfaat software microsoft excel dalam mengelolah data keuangan. Peserta berharap adanya pelatihan lanjutan sebagai upaya peningkatan keterampilan pengurus maupun anggota PKK RW 11 Desa Asrikaton Kecamatan Pakis Kabupaten Malang. Hampir seluruh peserta pelatihan sepakat bahwa microsoft excel dapat membantu proses pembuatan laporan keuangan dengan mudah dan cepat.

Bagi Jurusan Administrasi Niaga Politeknik Negeri Malang, kegiatan pelatihan ini merupakan realisasi salah satu Tri Dharma Perguruan Tinggi yatu Pengabdian Kepada Masyarakat (PKM). Disamping itu, adanya kerjasama pada kegiatan Pengabdian Kepada Masyarakat (PKM) ini akan memberikan kesempatan kepada dosen Jurusan Administrasi Niaga Politeknik Negeri Malang untuk melihat permasalahan pengelolaan data keuangan PKK RW 11 Desa Asrikaton Kecamatan Pakis Kabupaten Malang.

\subsection{Saran}

Saran yang dapat diberikan kepada organisasi mitra dan Jurusan Administrasi Niaga Politeknik Negeri Malang, adalah sebagai berikut:

Proses alih pengetahuan atau transfer ilmu membutuhkan proses yang panjang dan berkelanjutan, oleh karena itu disarankan agar khalayak sasaran atau peserta pengabdian yaitu pihak PKK RW 11 Desa Asrikaton Kecamatan Pakis Kabupaten Malang tidak berhenti berlatih hanya pada saat pelaksanaan kegiatan pengabdian kepada masyarakat saja. Pengurus PKK tetap menerapkan atau menggunakan keterampilan yang telah diperoleh dalam pengelolaan keuangan kas, dan koperasi PKK. Bagi peserta yang memiliki usaha mandiri dapat melakukan pemisahan keuangan usaha dan keuangan pribadi, serta tetap menggunakan keterampilan yang diperoleh untuk pengelolaan keuangan dengan komputer. Peserta tetap proaktif untuk memperdalam pengetahuannya dari berbagai sumber. 
Jurusan Administrasi Niaga Politeknik Negeri Malang hendaknya mengembangkan kerjasama tidak hanya pada perusahaanperusahaan besar/menengah saja, akan tetapi juga dengan organisasi masyarakat untuk pemberdayaan masyarakat, yaitu antara lain PKK RW 11 Desa Asrikaton Kecamatan Pakis Kabupaten Malang.

\section{DAFTAR PUSTAKA}

, 2008, Pengolah Angka : Microsoft Excel 2007, Jakarta: Web Media Training Centre,

Ikatan Akuntansi Indonesia, 2014. Standar Akuntansi Keuangan Entitas Tanpa Akuntabilitas Publik. Jakarta: Selemba Empat.

Fahmi, Ilham, 2012. Analisis Laporan Keuangan, Cetakan

Pertama,

Bandung:

ALFABETA.

Kasmir, 2014. Analisis Laporan Keuangan.

Cetakan Ketujuh, Jakarta: Rajawali Pers.

Munawir, S., 2007. Analisis Laporan Keuangan. Edisi ke Empat, Yogyakarta: Penerbit Liberty.

Riyanto, Bambang, 2012. Dasar-dasar Pembelanjaan Perusahaan, Yogyakarta: BPFE UGM. 